\title{
Review of the geology and paleontology of the Ellsworth Mountains, Antarctica
}

\author{
G.F. Webers ${ }^{1}$ and J.F. Splettstoesser ${ }^{2}$ \\ 'Department of Geology, Macalester College, St. Paul, MN 55108, USA (webers@macalester.edu) \\ ${ }^{2}$ P.O. Box 515, Waconia, MN 55387, USA (spletts@usfamily.net)
}

\begin{abstract}
The geology of the Ellsworth Mountains has become known in detail only within the past 40-45 years, and the wealth of paleontologic information within the past 25 years. The mountains are an anomaly, structurally speaking, occurring at right angles to the Transantarctic Mountains, implying a crustal plate rotation to reach the present location. Paleontologic affinities with other parts of Gondwanaland are evident, with nearly 150 fossil species ranging in age from Early Cambrian to Permian, with the majority from the Heritage Range. Trilobites and mollusks comprise most of the fauna discovered and identified, including many new genera and species. A Glossopteris flora of Permian age provides a comparison with other Gondwana floras of similar age. The quartzitic rocks that form much of the Sentinel Range have been sculpted by glacial erosion into spectacular alpine topography, resulting in eight of the highest peaks in Antarctica.
\end{abstract}

Citation: Webers, G.F., and J.F. Splettstoesser (2007), Review of the geology and paleontology of the Ellsworth Mountains, Antarctica, in Antarctica: A Keystone in a Changing World - Online Proceedings of the $10^{\text {th }}$ ISAES, edited by A.K. Cooper and C.R. Raymond et al., USGS OpenFile Report 2007-1047, Short Research Paper 107, 5 p.; doi:10.3133/of2007-1047.srp107

\section{Introduction}

The Ellsworth Mountains are located in West Antarctica (Figure 1) with dimensions of approximately $350 \mathrm{~km}$ long and $80 \mathrm{~km}$ wide. They are divided by the east-flowing Minnesota Glacier into the Sentinel Range to the north and the Heritage Range to the south. The rugged topography is evident by alpine features eroded from quartzitic rocks that exhibit the highest peaks in Antarctica, with 8 peaks between 4359 and $4892 \mathrm{~m}$ in elevation (Gildea and Splettstoesser, 2007). The more than 13,000-m-thick stratigraphic succession ranges in age from Cambrian to Permian, and exhibits similarities to other Gondwana sequences in the southern hemisphere and India. Glacial deposits, coal beds, and plants of Permian age are parts of this common sequence, including the first occurrence of Glossopteris in West Antarctica (Craddock et al., 1965). The abundance and variety of fossils in the Cambrian and Devonian sequences are unique, with numerous new genera and species of mollusks and other fauna figured and named.

No obvious basement rocks have been discovered, although Precambrian rocks are presumably at depth, as indicated by a Precambrian age of the nearby Haag Nunatak ( $\left.77^{\circ} \mathrm{S}, 78^{\circ} 18^{\prime} \mathrm{W}\right)$ (Clarkson and Brook, 1977). $\mathrm{A}$ U-Pb zircon date of $512 \pm 14 \mathrm{Ma}$ in volcanic rocks of the Union Glacier Formation (Rees et al., 1997, suggests that the rocks that were intruded could be Precambrian in age.

An alignment with a similar sequence in the nearby Transantarctic Mountains, however, is not shown, with the strike of the Ellsworth Mountains at nearly right angles to the former, as well as to the Antarctic Peninsula to the northwest. The movement of the Ellsworth Mountains, along with the nunataks to the south (Pirrit, Nash, and Martin Hills; Whitmore Mountains; Pagano Nunatak), denoted here as the EWM crustal block, as a microplate and concurrent uplift, has been analyzed by several investigators, with many reconstructions proposed

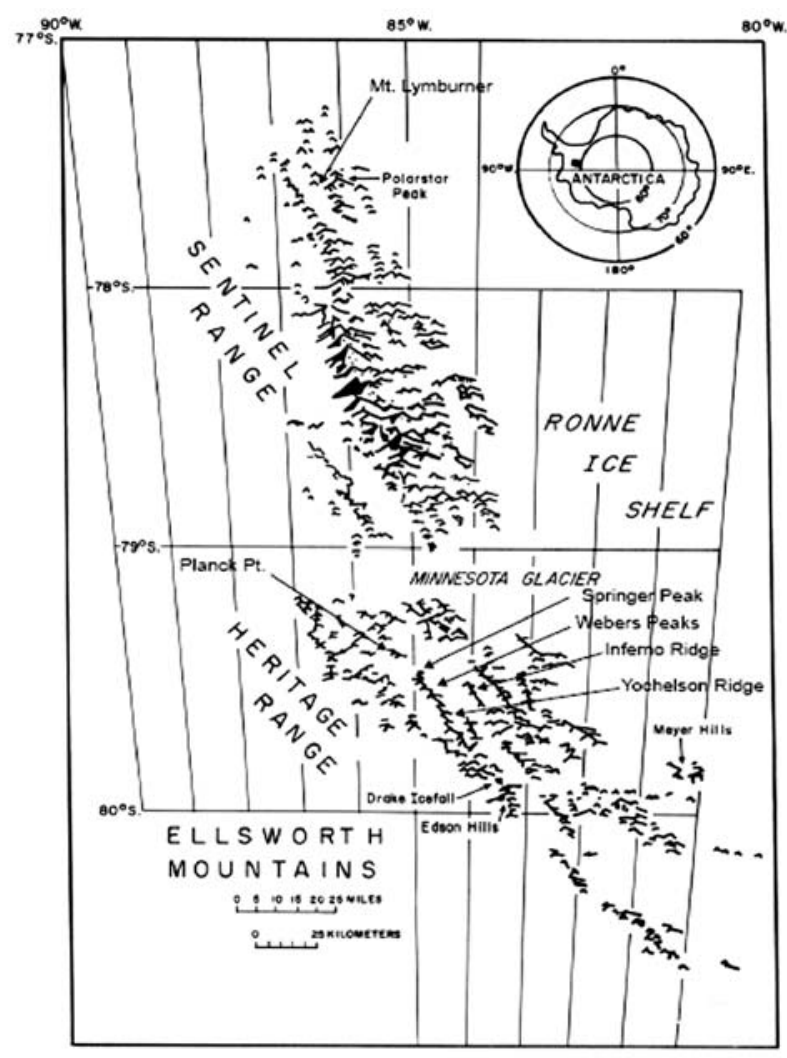

Figure 1. General location map of the Ellsworth Mountains (modified from original sketch map by J.J. Anderson in Anderson et al., 1962).

(see Webers et al., 1992, p. 6 for a summary). Over half of the stratigraphic column (Figure 2) was deposited during the Cambrian, when volcaniclastic sediments were deposited in a rift basin on the margin of Gondwana. Following the Cambrian the Ellsworth basin became a slowly subsiding, semi-stable sedimentary region. The 


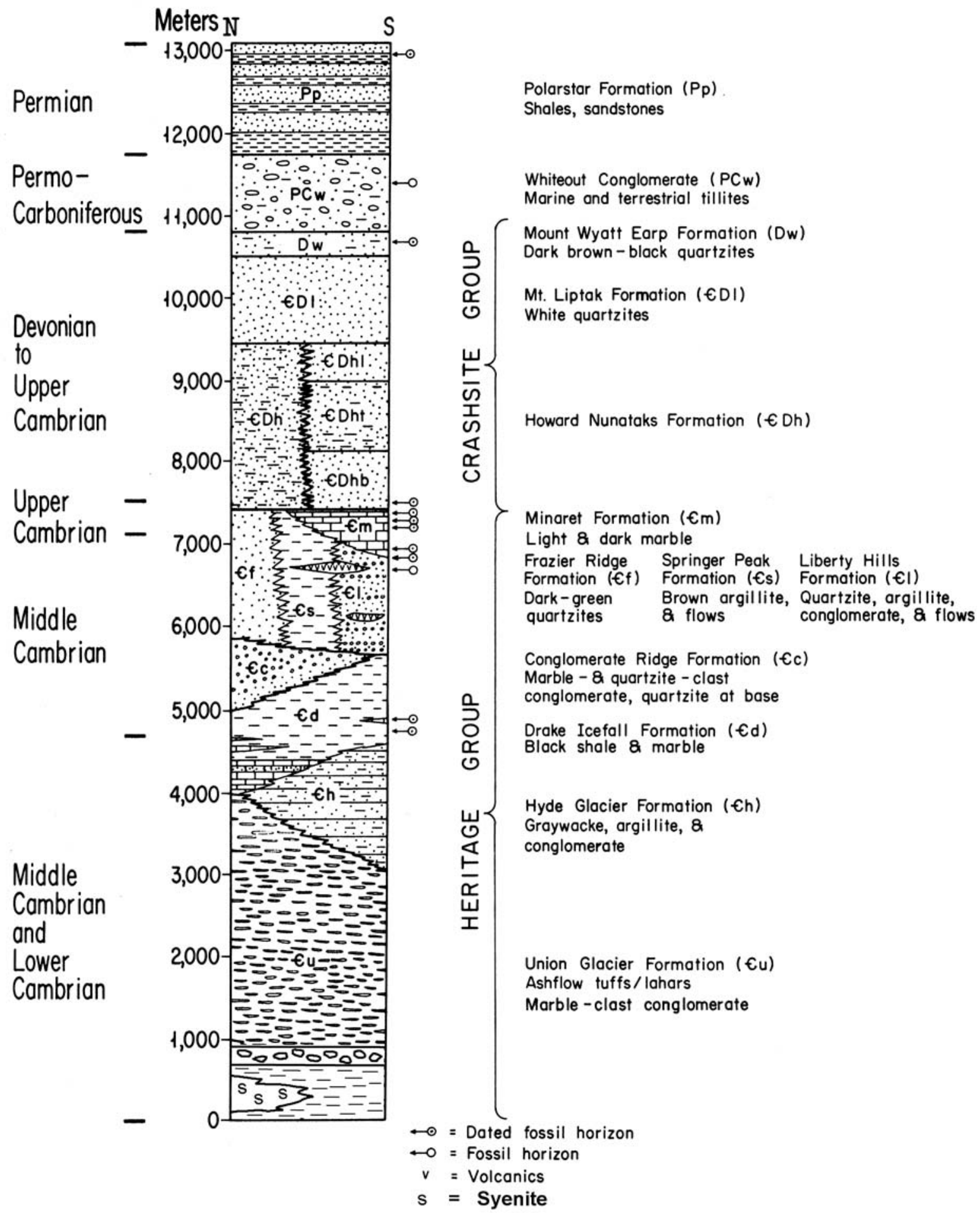

Figure 2. Columnar section of the Paleozoic rocks exposed in the Ellsworth Mountains, West Antarctica.

Ellsworth Mountains sequence was deformed and metamorphosed in Early Jurassic time (Craddock, 1969).

\section{Paleontologic history}

Geologic investigations in the Ellsworth Mountains have yielded a treasure-trove of paleontological information. Twenty-seven localities have yielded 17 fossil faunas and one fossil flora. These sites exhibit 148 species ranging in age from Early Cambrian to Permian. The majority of the fossil sites are in the Heritage Range. The reader is referred to the volume on "Geology and Paleontology of the Ellsworth Mountains, West 
Table 1 Major fossil faunas/floras from the Ellsworth Mountains, West Antarctica.

\begin{tabular}{|c|c|c|c|c|c|c|}
\hline Localities & Formation & Age & Lithology & $\begin{array}{l}\text { Dominant } \\
\text { Fossils }\end{array}$ & Comments & References* \\
\hline Polarstar Peak & Polarstar & Permian & $\begin{array}{l}\text { Argillite \& } \\
\text { Sandstone }\end{array}$ & $\begin{array}{l}\text { Glossopteris } \\
\text { Flora }\end{array}$ & $\begin{array}{l}\text { Typical } \\
\text { Flora }\end{array}$ & $\begin{array}{l}\text { Taylor \& Taylor } \\
\text { p.285-294 }\end{array}$ \\
\hline Planck Point & $\begin{array}{l}\text { Mount Wyatt } \\
\text { Earp }\end{array}$ & Devonian & Quartzite & $\begin{array}{l}\text { Inarticulate } \\
\text { Brachiopods }\end{array}$ & $\begin{array}{r}\text { Diverse but } \\
\text { Sparse Fauna }\end{array}$ & $\begin{array}{l}\text { Webers et al. } \\
\text { p. } 269-278\end{array}$ \\
\hline $\begin{array}{l}\text { Springer Peak } \\
\& \text { Webers Peaks }\end{array}$ & Minaret & $\begin{array}{c}\text { Late } \\
\text { Cambrian }\end{array}$ & Limestone & $\begin{array}{l}\text { Trilobites \& } \\
\text { Molluscs }\end{array}$ & $\begin{array}{l}\text { Spectacular } \\
\text { Fauna }\end{array}$ & $\begin{array}{l}\text { Webers et al. } \\
\text { p. } 181-248\end{array}$ \\
\hline “ & “ & “ & “ & Conodonts & Recrystallized & $\begin{array}{l}\text { Buggisch et al. } \\
\text { p.169-179 }\end{array}$ \\
\hline “ & “ & “ & F & $\begin{array}{c}\text { Brachiopods } \\
\text { Pelmatozoa } \\
\text { Archaeo- } \\
\text { cyathids }\end{array}$ & $\begin{array}{l}\text { Mostly } \\
\text { Inarticulate } \\
\text { Brachiopods }\end{array}$ & $\begin{array}{l}\text { Henderson et al. } \\
\text { p. } 249-267\end{array}$ \\
\hline “ & “ & “ & “ & Trilobites & $\begin{array}{l}\text { Abundant } \\
\text { Fauna }\end{array}$ & $\begin{array}{l}\text { Shergold \& Webers } \\
\text { p. } 125-168\end{array}$ \\
\hline Yochelson Ridge & Minaret & $\begin{array}{r}\text { Middle } \\
\text { Cambrian }\end{array}$ & Limestone & Trilobites & $\begin{array}{l}\text { Abundant } \\
\text { Fauna }\end{array}$ & $\begin{array}{l}\text { Jago \& Webers } \\
\text { p. } 101-124\end{array}$ \\
\hline Meyer Hills & $\begin{array}{c}\text { Whiteout } \\
\text { Conglomerate }\end{array}$ & $\begin{array}{c}\text { Early } \\
\text { Cambrian }\end{array}$ & $\begin{array}{l}\text { Carbonate } \\
\text { Clasts }\end{array}$ & $\begin{array}{l}\text { Archaeo- } \\
\text { cyathids }\end{array}$ & $\begin{array}{l}\text { Archaeo- } \\
\text { cyathan Fauna } \\
\text { from Clasts }\end{array}$ & $\begin{array}{c}\text { Debrenne } \\
\text { p. } 279-284\end{array}$ \\
\hline Mt. Lymburner & “ & “ & “ & “" & ، & “ \\
\hline Edson Hills & Drake Icefall & $\begin{array}{c}\text { Early } \\
\text { Cambrian }\end{array}$ & $\begin{array}{l}\text { Carbonate } \\
\text { Clasts } \\
\text { Algae }\end{array}$ & $\begin{array}{l}\text { Archaeo- } \\
\text { cyathids \& } \\
\text { Skeletal }\end{array}$ & $\begin{array}{l}\text { Sparse } \\
\text { Fauna/ } \\
\text { Flora }\end{array}$ & $\begin{array}{l}\text { Buggisch \& Webers } \\
\text { p. } 81-100\end{array}$ \\
\hline
\end{tabular}

Antarctica" (Webers et al., 1992) for details on the fossils described below. Table 1 lists major fossil faunas/floras from the Ellsworth Mountains, and Figure 3 illustrates representative fossils.

The Late Cambrian trilobite-mollusk fauna at Springer Peak is truly remarkable. It is perhaps the best preserved and most diverse of any fauna of Late Cambrian age anywhere in the world. Seven phyla are represented, including Arthropoda, Mollusca, Brachiopoda, Hyolitha, Echinodermata, Pisces, and Archaeocyatha. Some 70 species are present. The fauna is found in an 8-m-thick feather-edge of the Minaret Formation that thickens to as much as $600 \mathrm{~m}$ to the south. To the south, severe deformation has generally destroyed the fossils. At Springer Peak the feather-edge was bounded above and below by incompetent argillites which took up the deformational strain. The fossils are three-dimensional. Preservation is excellent and shells are present. Much of the material is a coquina of fossils. Space does not permit illustration of this remarkable fauna.

Trilobites make up the majority of the material with about $8 \%$ being made up of mollusks. Twenty species of trilobites, including agnostids, show affinities to North America, Australia, China and southern Russia. The mollusks are perhaps the most noteworthy. They include seven species of monoplacophora, six species of gastropods, three species of rostroconchs and an orthothecid.

The monoplacs (monoplacophorans) are perhaps the most significant. They are generally very rare in Late Cambrian faunas. At Springer Peak they are present in great numbers and diversity. We believe that the monoplacs are ancestral to the cephalopods, rostroconchs, bivalves, and gastropods.

Monoplacs are typically low, cap-shaped, single shells. The Springer Peak monoplacs also contain a number of high-coned forms. We believe one of these, Knightoconus (Yochelson et al., 1973) to be representative of a group that is ancestral to the cephalopods. It is a high-coned, multiseptate species but lacks the siphuncle of the cephalopods (Figure 3, no.6). The first known cephalopods are slightly younger and are from China. They are a little more elongate than Knightoconus and have a small siphuncle along the ventral margin. Both forms are multiseptate and curved in a similar manner.

Six species of gastropods and three species of rostroconchs are present. Rostroconchs are clam-like in appearance but have only one shell. Rostroconchs probably lived like modern clams. A single species of an orthothecid was also recovered. 


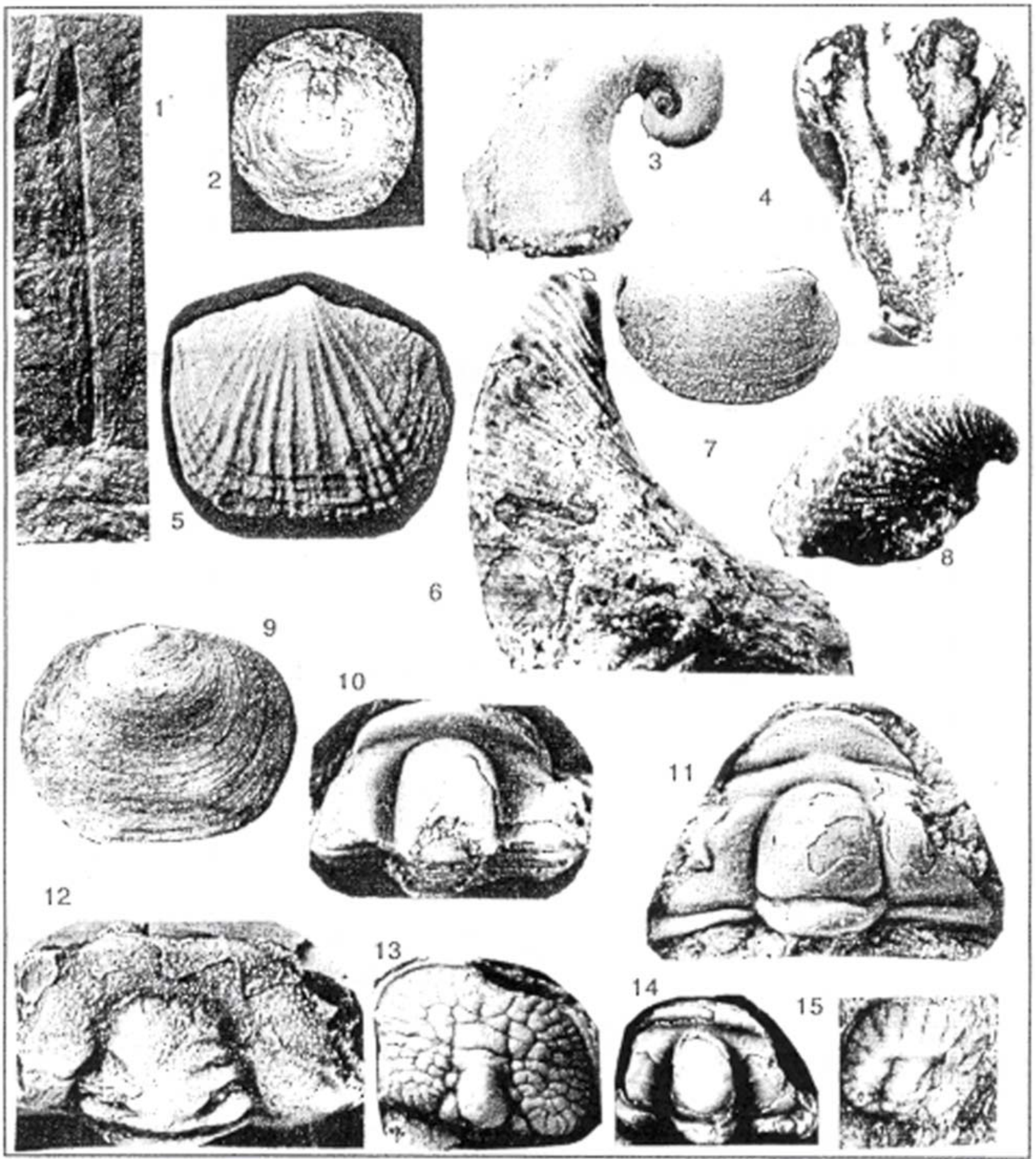

Figure 3. Representative Fossils from the Ellsworth Mountains (from Webers et al. (1992). 1. Glossopteris cf. tortuosa, x 2, Chap. 14, P1. 1, p. 291; 2. Orbiculoidea cf. falklandensis, x1.5, Chap. 12, Pl. 1, p. 277; 3. Euomphalopsis splettstoesseri, x3, Chap. 10, Pl. 7, Fig. 11, p. 221; 4. Antarcticocyathus webersi, x2.5, Chap. 11, P1. 5, Fig. 1, p.267; 5. Billingsella cf. borukaevi, x3.5, Chap. 11, Pl. 4, Fig. 5, p. 265; 6. Knightoconus antarcticus, x3, Chap. 10, P1. 16, Fig. 2, p. 239; 7. Ribeiria australiensis, x10, Chap. 10, Pl. 1, Fig. 9, p. 209; 8. Proplina rutfordi, x10, Chap, 10, P1. 12, Fig. 13, p. 231; 9. Angulotreta ellsworthensis, x30, Chap. 11, Pl. 1, Fig. 1, p. 259; 10. Sohoplura drakensis, x6, Chap. 7, Pl. 3, Fig. 1, p. 119; 11. Onchopeltis? cf. neutra, x6, Chap. 8, Pl. 5, Fig. 7, p. 155; 12. Pseudobergeronites spinosa, x3, Chap. 7, Pl. 4, Fig. 5, p. 121; 13. Glyptagnostus reticulatus, x6, Chap. 8, P1. 2, Fig. 14, p. 149; 14. Pagetia edsonensis, x3.4, Chap. 7, Pl. 2, Fig. 24, p. 117; 15. Tomagnostella sp., x8, Chap. 7, Pl. 2, Fig. 1, p. 117. 
Late Cambrian mollusks are geographically widespread in China, Australia and North America. The Minaret mollusks are closest to a molluskan fauna found at Taylors Falls, Minnesota, U.S.A. The Minnesota material, however, is poorly preserved in sandstone as internal and external molds.

In addition to the mollusks and the trilobites, a variety of other forms are present in the Minaret fauna. Archaeocyathids were thought to be confined to the Lower Cambrian. The Minaret fauna contains the firstknown Late Cambrian archaeocyathid. Scattered columnals of pelmatozoa are present and cover some bedding surfaces. Nine species of inarticulate brachiopods and a single species of articulate brachiopod are present. Ten species of conodonts were also recovered. Trilobite faunas were also collected from five localities (Springer Peak, Pojeta Peak, Drake Icefall area, Edson Hills, and Yochelson Ridge) by M.N. Rees (personal communication, 2006) during expeditions in 1993 and 1995. Descriptions of these faunas have not been published.

A Lower Devonian fauna has been recovered near Planck Point in the Heritage Range. The fauna is diverse but rather sparse. The inarticulate brachiopod Orbiculoidea cf. falklandensis (Webers et al., 1992) is the most common fossil. Other forms present include two species of bivalves, and one species each of a cephalopod, rostroconch, gastropod, conularid, trilobite, and articulate brachiopod. A single fish spine was recovered. The fauna correlates with those of the Lower Devonian of the Horlick Formation, Ohio Range, Horlick Mountains, and the Lower Devonian of the Falkland Islands.

A Middle-to-Late Permian flora has been collected from four localities of the Polarstar Formation in the northern Sentinel Range. This is the so-called Glossopteris flora. Fifteen species of Glossopteris dominate the flora. Two species of Gangamopteris are also present, as are two species of Sphenophyta. An insect wing was also recovered (Tasch and Riek, 1965).

The flora in the Ellsworth Mountains appear most similar to floras from the Ohio Range of the Horlick Mountains, the Theron Mountains, Whichaway Nunataks, southern Victoria Land, and the Falkland Islands.

\section{Summary}

The faunas and flora of the Ellsworth Mountains have provided abundant information on evolution, environmental conditions, and dating. Correlation of these fossils with the Ohio Range of the Horlick Mountains seems to be the most consistent, and fits in well with the theory that the Ellsworth Mountains once occupied a position adjacent to the Pensacola Mountains of the Transantarctic Mountains.

Acknowledgments. This article is dedicated to Campbell Craddock (deceased 23 July 2006), who led the way toward significant discoveries in the Ellsworth Mountains, Antarctica, and to Ellis Yochelson (deceased 30 August 2006), a major contributor toward field collecting and identification of many of the fossils described in Webers et al. (1992). Editorial assistance and advice from W. LeMasurier are appreciated, as well as initiating the special session for C. Craddock. The manuscript benefited from reviews by J. Collinson, J. Craddock, and R. Ojakangas.

\section{References}

Anderson, J.J., T. Bastien, P.G. Schmidt, J.F. Splettstoesser, and C. Craddock (1962), Antarctica: Geology of the Ellsworth Mountains, Science, 138, 824-825.

Clarkson, P.D., and M. Brook (1977), Age and position of the Ellsworth Mountains crustal block, Nature, 265, 615-616.

Craddock, C. (1969). Geology of the Ellsworth Mountains, in Geologic maps of Antarctica, edited by V.C. Bushnell and C. Craddock, American Geographical Society, Antarctic Map Folio Series, Folio 12, Plate 4, New York.

Craddock, C., Bastien, T.W., Rutford, R.H., and J.J. Anderson (1965), Glossopteris discovered in West Antarctica, Science, 148, 634-637.

Duebendorfer, E.M., and M.N. Rees (1998), Evidence for Cambrian deformation in the Ellsworth-Whitmore Mountains terrane, Antarctica: Stratigraphic and tectonic implications, Geology, 26, 5558.

Gildea, D., and J. Splettstoesser (2007), Craddock Massif and Vinson Massif remeasured, in Antarctica: A Keystone in a Changing World Online Proceedings of the $10^{\text {th }}$ ISAES, edited by A.K. Cooper and C.R. Raymond et al., USGS Open-File Report 2007-xxx, yyy, 1-4, doi: $10.3133 z z z z z z$.

Rees, M.N., Smith, E.I., Keenan, D.L., and E.M. Duebendorfer (1997), Cambrian magmatic rocks of the Ellsworth Mountains, West Antarctica, Antarctic Journal of the United States, 32, 3-5.

Tasch, P., and E.F. Riek (1969), Permian insect wing from Antarctic Sentinel Mountains, Science, 1964, 1529-1530.

Webers, G.F., Craddock, C., and J.F. Splettstoesser, editors (1992), Geology and Paleontology of the Ellsworth Mountains, West Antarctica, Geological Society of America Memoir 170, 459 pp.

Yochelson, E.L., Flower, R.H., and G.F. Webers (1973), The bearing of the new Late Cambrian Monoplacophoran genus Knightoconus upon the origin of the Cephalopoda, Lethaia, 6, 275-310. 